\title{
VEDó Attila \\ A Magyar Királyi Csendőrség \\ karhatalmi tevékenységének szabályozása a dualizmus idején
}

A dualizmus időszakában a karhatalmi fellépés fogalomköre alatt sokkal szélesebb tevékenységi kört értettek, mint amit napjaink szóhasználata lefed. A karhatalom nem jelentett egyet az úgynevezett csapaterővel végrehajtott feladatokkal, hanem a közigazgatás müködésének olyan támogatását értették a fogalom alatt, melyben a legitim fizikai erőszak állami monopóliumával bíró fegyveres testületek jelenléte vagy intézkedése volt szükséges. A korszakban mindenképpen meg kell különböztetni a „karhatalom” és a „rendőri segély” fogalmát, melyek között azonban nem volt éles határvonal. Nem különült el élesen a rendvédelmi és a honvédelmi, azaz a haderő alakulataival megvalósított karhatalmi tevékenység sem, hiszen a Magyar Királyi Csendőrségen túl szükség esetén a hadsereg csapatai is részt vettek közbiztonsági jellegű feladatokban. A karhatalmi tevékenység és határterületei áttekintéséhez elengedhetetlen a korabeli közigazgatási struktúra és jogszabályrendszer értékelése, amely alapjaiban határozta meg a csendőrség csapaterős feladatait.

\section{A karhatalom fogalmának értelmezése a dualizmus korában}

A korabeli közigazgatási nyelvezetben és jogszabályi szóhasználatban a karhatalom kifejezést több, eltérő jelentést hordozó értelemben alkalmazták, melyek nem egyszer ellentétben álltak a szó által leírt intézkedés tartalmával. A szó jelentése is változott, árnyaltabb értelmet kapott az idők folyamán, így míg kezdetben a „karhatalmi” szinte egyet jelenthetett a „közbiztonsági” fogalommal, később inkább a mai értelemben vett csapaterő alkalmazását jelentette. A „karhatalom” kifejezés folyamatos pontosításra, értelmezésre szorult a közigazgatásban, mivel esetenként akár néhány fós erőt is így neveztek meg. Megjegyzendő azonban, hogy például az idézésre meg nem jelent személy elővezetésére kiküldött 2 fös csendőr járőr is karhatalmi személyzet volt, mivel a fogalmi ismérveknek teljes mértékben megfelelt.

A karhatalom nem volt más, mint a fenyegetett törvényesség biztosítására, a megzavart közrend helyreállítására kirendelt fegyveres erő. A szó közönséges értelmében a karhatalom olyan segítséget jelentett, amely fegyveresen jelent meg és éppen fegyverének tekintélyével oszlatta el a törvényességet fenyegető veszedelmet és állította helyre a megzavart közrendet. A haderő kifejezés itt szándékos, hiszen ezen fogalom alá csak a szárazföldi haderő és a haditengerészet értendő, viszont a rendőri közegek és a csendőrség — mivel a belső rend fenntartására voltak hivatottak — nem. Meg kell különböztetni tehát rendvédelmi és honvédelmi karhatalmat. A rendvédelmi karhatalomba természetesen beletartozik a csendőrség is mint rendvédelmi testület, annak ellenére, hogy a csendőrök személyükben katonának minősültek. A haderő igénybevételének csak az adott helyen és időben rendelkezésre álló rendvédelmi erő elégtelensége esetén lehetett helye. Összességében karhatalmi teendőnek tartották azokat a tevékenységeket, amelyek megvalósítása során fizikai kényszert alkalmaztak, vagy ilyen kényszer demonstrálása szükséges volt. Ebből adódóan tehát a karhatalmi tevékenységek ellátására azon szervezetek voltak alkalmasak, amelyek az adott rendvédelmi célfeladat ellátása érdekében fizikai kényszer alkalmazására is jogosultak és képesek voltak. ${ }^{1}$ A rendvédelmi csapaterős teendők a vizsgált időszakban a karhatalmi feladatoknak csupán egy részét, a karhatalmi tevékenységi körnek csupán legvégső állomását képezték, és csak akkor alkalmazták, amikor más jellegü megoldások már alkalmatlanok voltak. ${ }^{2}$

A Magyar Királyi Csendőrség karhatalmi alapfeladatát döntően a tágabb értelemben vett karhatalmi tevékenység képezte. A csendőrség jellegéből fakadóan azonban a csapaterős teendők ellátását is mind inkább e testülettől várta a közigazgatás, azonban - főleg a csendőrség teljes megszervezéséig katonai csapatokat is igényelhettek szigorúan szabályozott keretek között. A véderő csapatait általában akkor vonták be a csapaterős rendvédelmi tevékenységek megvalósításába, ha arra a csendőrség valamilyen okból elégtelennek mutatkozott.

A haderő rendvédelmi célú alkalmazására nemcsak rendkívüli viszonyok között, hanem a Magyar Királyi Csendőrség létrehozásakor is volt példa, bár nem a klasszikus értelemben. Az 1885. IV. 22-én kelt legfelső elhatározás alapján honvédeket osztottak be a szerveződő csendőrségbe, mint „karhatalmi segédeket". A kiegészítés létszáma kezdetben 1200 fö volt, majd a szükséges számban történt. ${ }^{3}$ A honvéd karhatalmi segédek vezénylése 1887-ben szünt meg és ezt követően az egyes honvédek önálló rendvédelmi alkalmazása tilos volt, ezt a csendőr járőrök megerősítése tárgyában kiadott belügyminiszteri rendelet jogszabályi szintre is emelte. ${ }^{4}$ 


\section{A karhatalom viszonya a közigazgatáshoz}

A csendőrségi karhatalom igénye már 1867-ben is gyakran felmerült és egyre több hatósági eljárás követelte minisztériumi szintủ iránymutatások kiadását. Az igazságügy miniszter 1867. VI. 22-én kelt rendeletében megfogalmazta, hogy a magánjogi és bírósági ügyekből eredő karhatalmi igények kielégítésre „a csendörséget helyettesitö s ennek teendőivel megbizott közegek alkalmaztassanak." azonban olyan esetek, amikor a rendvédelmi közegek a feladat végrehajtására nem álltak rendelkezésre, így továbbra is haderő támogatta a hatósági eljárásokat. A felvonulás költségeit ekkor a kirendelő hatóság viselte. ${ }^{6}$ A belső rend fenntartásának feladataira a haderő folyamatos kirendelése azonban nem volt fenntartható a fejlődő polgári államban. A közigazgatást minden tekintetben kiszolgálni képes, professzionális és központosított szervezetre volt szükség. A Magyar Királyi Csendőrség felállításával a legtöbb probléma megoldódott, hiszen a testület első szolgálati utasítása a szerint a csendőrség a közcsend, rend és biztonság fenntartása érdekében a közigazgatási hatóságok rendelkezése alatt állt. Ezek hivatalos felszólításainak feltétlenül engedelmeskedni tartozott és a felhívás megbírálásába nem bocsátkozhatott. ${ }^{7}$ A karhatalom körében jelentkező számtalan feladat végrehajtására azonban a csendőrség önmagában nem volt képes. Komolyabb fegyveres erő felvonultatását továbbra is csak a haderő tudta biztosítani, a csendőrségi karhatalmat más rendvédelmi szervezet létszámánál és felszerelésénél fogva sem tudta támogatni. A dualizmus időszakában mintegy 33378 fő teljesített szolgálatot a Magyar Királyság állami és önkormányzati rendvédelmi testületeinél. Az állami és önkormányzati rendörségeknél 12600 fö, a Magyar Királyi Csendőrségnél 12000 fö, a büntetés-végrehajtásnál 3000 fö, a Magyar Királyi Pénzügyőrségnél 5500 fö, a magyar testőrségeknél 142 fö, a Magyar Királyi Koronaőrségnél 58 fö, a Magyar Királyi Képviselőházi Orségnél 78 fö. A legtágabb értelmü karhatalmi teendők ellátásában sem vett részt a Magyar Királyi Nemesi Testőrség és a Magyar Királyi Darabont Testőrség 142 fős, a Magyar Királyi Képviselőházi Örség 78 fős, a Magyar Királyi Koronaőrség 58 fős, és a büntetés-végrehajtás 3000 fős létszámú szervezete. E testületek 3278 főnyi létszáma a korabeli magyar rendvédelemben foglalkoztatott 33378 fönek a 9,82 \%-át tette ki. A tágabb értelemben vett karhatalmi feladatok teljesítésében részt vehettek a rendőrségek 12600 fövel és a Magyar Királyi Pénzügyőrség 5500 fövel, valamint a Magyar Királyi Csendőrség 12000 fővel. Összesen 30100 fővel, amely a 33078 főnyi rendvédelmi létszám 90,18 \%-át tette ki. ${ }^{8}$ A mai viszonyokhoz képest szerény létszámú szervezetek széttagolt, elszórt díszlokációval rendelkeztek, ami jelentősen korlátozta az összpontosítások idejét és méretét, valamint felszerelésük, fegyverzetük sem volt alkalmas — a Magyar Királyi Csendőrség kivételével — a belső rend csapaterős fellépéssel történő helyreállítására.

Valószínüleg a szervezetek alacsony létszáma és a fellépésüket kísérő nagyobb tekintély eredményezték, hogy a csapaterős karhatalmi feladatokra kirendelt csendöri erő legfeljebb örs vagy szakasz erejü volt. A legnagyobb mérvü erőkoncentráció, amelyet a dualizmus időszakában kialakítottak zászlóalj erejü volt és ennek létszáma sem haladhatta meg a 300 föt. A Magyar Királyságban 33378 főnyi létszámmal müködő testületek személyi állományából tehát maximálisan mintegy 300 fö látott el egy idôben csapaterős karhatalmi feladatot, amely a rendvédelmi testületek személyi állományának $0,80 \%$-át tette ki. ${ }^{9}$

Nemcsak a rendelkezésre álló létszám, hanem a karhatalmi igénybevétel tekintetében is lényegesen eltért a csendőrség korának többi rendvédelmi szervezetétől. Egyrészt a csendörség katonailag szervezett őrtestület volt, ami azt jelentette, hogy a csendőr személyében katonának minősült, katonai rangot viselt, és a személyi állomány függelmi viszonyai is katonaiak voltak. Az állomány felkészültsége tartalmazta a csapaterős karhatalmi alkalmazásra vonatkozó ismereteket, ami a katonai kiképzésen és a kötelékben végrehajtott harceljárások ismeretén alapult. Az egyéni fegyverzet szintén alkalmassá tette a személyi állományt a csapaterös fellépésre. ${ }^{10}$ A mai szemmel radikálisnak tünő szuronytámadás és lőfegyverhasználat kapcsán szükséges megjegyezni, hogy a kirendelt karhatalom fellépése a rendelkezésére álló felszereléshez igazodott, amely katonai volt. Ennek megfelelően katonai taktikát alkalmaztak és gyalogsági (vagy épp lovassági) kötelékharcként értelmezték a rendvédelmi fellépést. Természetesen itt a fellépés célja nem az ellenség megsemmisítése volt, hanem a közrend helyreállítása és a tömeg szétoszlatása. Ez a felfogás megfelelt a korabeli Európa rendvédelmi gondolkodásának, hiszen a francia csendörségnél is csak 1929-ben merült fel a gumibot rendszeresítésének kérdése. ${ }^{11}$

A csendőrség másik lényeges vonása, amely megkülönböztette más rendvédelmi szervezetektöl és föképp a rendôrségektől a kompetenciája volt. A dualizmus-korszakbeli rendőrségek önálló hatósági jogkörrel rendelkeztek. Ezzel szemben a Magyar Királyi Csendőrség feladatát a közigazgatási intenciók megvalósításának biztosítása képezte. A csendőrség azonban szolgálatellátás során szembetalálta magát olyan élethelyzetekkel, amikor a közigazgatási hatóságok intelmeit nélkülözve is el kellett járnia. Ezeket nevezeték az úgynevezett rendes szolgálat körébe tartozó feladatoknak. A Magyar Királyi Csendörség tehát olyan rendvédelmi testület volt, amelyet azzal a céllal hoztak létra, hogy a közigaz- 
gatási döntések végrehajtását szükség szerint ki is kényszerítse akár fizikai erő, kényszerítő intézkedések, végső soron fegyverhasználat által is. ${ }^{12}$

A rendvédelmi testületek csapaterős rendvédelmi teendők ellátására alkalmassá tett szervezeti egységei nem rendelkeztek monopóliummal a karhatalmi teendők ellátását illetően. Ilyen jellegü feladatokra a haderő a fentiek tükrében továbbra is igénybe vehető volt, melybe csapatait rendszeresen bevonták. A dualizmus időszakában a véderő részei közül elsősorban a Magyar Királyi Honvédség csapatait vették igénybe a csapaterős rendvédelmi feladatok ellátására ${ }^{13}$ bár a jogi szabályozásból a közös hadsereg elsőbbsége következett volna hasonló esetekben. A haderő alakulatainak rendvédelmi csapaterös feladatok ellátására történő igénybevételét a korabeli honvédelmi törvények tették lehetővé, az igénybevétel módját pedig rendeletekben és szabályzatokban rögzítették. A véderő rendvédelmi csapaterös feladatokba történő bevonása sem tekinthető magyar sajátosságnak, mivel hasonló volt a helyzet a környező országokban, illetve a kontinens vezető hatalmai, Németország és Franciaország tekintetében is. ${ }^{14}$ A haderő alakulatainak karhatalmi célra történő igénybevétele nem csorbította a kivételes hatalomról szóló ${ }^{15}$ törvénycikkben foglaltakat, ugyanis erre nem csupán a kivételes hatalom időszakában került sor, illetve a karhatalom végső soron a polgári hatóság felügyelete alá került. A polgári közigazgatás rendelkezésére bocsátott karhatalmak és segédletek után a civil hatóságoknak a honvédelmi tárca felé külön elszámolás szerint térítést kellett fizetniük. A honvédségi alakulatokat például pénzügyőri szolgálatokra, közigazgatási vagy közbiztonsági célokra (pl. vesztegzár, záróvonal fenntartása, foglyok őrkísérete, rablók elleni kiküldetések), a hatóságok által kibocsátott rendelkezések és tilalmak végrehajtására, adóvégrehajtó különítményként, postakíséretül, árvizeknél és más elemi csapásoknál segítségnyújtásra, polgári közigazgatás alá tartozó pénztárak, börtönök és egyéb intézetek őrizetére éppúgy igénybe lehetett venni, mint a fentiekre elsődlegesen szánt csendőri erőt. ${ }^{16}$ A dualizmus időszakában tehát nem emeltek áthidalhatatlan akadályokat a külső és a belső védelem megvalósítására létesített testületek igénybe vétele elé a rokon szakterületeken. A fövárosi rendörség detektív testületét például szükség esetén bevonták az ellenséges hírszerzők elleni akciókba és a haderő csapatait is igénybe vették karhatalmi teendők ellátására. A korabeli gyakorlat - egy-egy feladatot illetően a testületek alkalmasságát tekintette mérvadónak. A törvényi szabályozás a rendfenntartás jogosultságait nem a rendvédelmi testületekhez, hanem az önkormányzatokhoz, illetve a központi államhatalomhoz telepítette. Törvényt a rend védelmére és nem a rendőrségre, mint szervezetre alkottak. A rend védelméért felelős központi állami és önkormányzati szervezetek hozhattak létre rendvédelmi testületeket rendvédelmi kötelezettségeik eredményes megvalósítása érdekében. ${ }^{17}$

A csendőrség és különösen a csendőrségi karhatalom kirendelésének közigazgatási kapcsolódásainak részletes tárgyalása előtt szükséges áttekinteni a magyar igazgatási struktúra három kulcsfontosságú szintjét: a föispán, az alispán és a (fö)szolgabíró helyét és szerepét.

A főispán a kormány képviselöje volt a törvényhatósági közigazgatásban, akit a belügyminiszter előterjesztésére és ellenjegyzése mellett a király nevezett ki. Állása így politikai természetű volt és bármikor elbocsáthatták hivatalából. Hatásköre kettős: a törvénykezési és katonai hatóságok és hivatalok kivételével egyrészt a törvényhatóság területén levő kormányközegek, királyi hatóságok müködésére, másrészt a törvényhatóság által teljesített autonóm és állami közigazgatásra terjedt ki. Joga volt az állami szervezetek eljárását ellenőrizni, azoktól konkrét esetekre vonatkozólag felvilágosítást követelni. A föispán volt a törvényhatósági közgyülés elnöke is. Teendői a következő szempontok szerint csoportosíthatók a föispáni „rendes hatalom” körében:

- általános ellenőrzési felügyeleti teendők;

- rendelkezés, rendelet, utasítás kibocsátás a felügyeleti, ellenörzési jogkörön belül;

- fegyelmi hatalom gyakorlása;

- szervezeti és kinevezési, kijelölési, áthelyezési, helyettesítési, beosztási teendők.

Ha a törvényhatóság vagy annak első tisztviselöje, nem teljesítette a kormányrendeletek végrehajtására vonatkozó kötelességét, a minisztérium fölhatalmazhatta a föispánt, hogy a törvényhatóság szükséges tisztviselőivel és közegeivel közvetlenül rendelkezhessék. ${ }^{18} \mathrm{Ez}$ volt a föispán rendkívüli hatalma.

A fentiekből is látható, hogy a politikai funkciók gyakorlása mellett komoly végrehajtó hatalom is összpontosult a föispán kezében, ami a tárgyalt időszak közjogi szabályozásában azt eredményezte, hogy a karhatalommal való közvetlen rendelkezés jogától idővel megfosztották. Ez komoly lépésnek tekinthető, hiszen az állami vezetés felismerte, hogy a karhatalom, különösen a közigazgatás közvetlen rendelkezése alatt álló csendőrségi karhatalom nem kellő körültekintéssel vagy politikai célok érdekében történő felhasználása súlyos következményekkel járhat. 
Az alispán a főispán helyettese volt már a nemesi vármegyében is. Az alispán — a politikai színtéren mozgó föispán helyett - a vármegye professzionális közigazgatási funkcionáriusaként tevékenykedett. A kinevezett föispánnak nem volt alárendelve, hanem önállóan intézte a megyei közigazgatás ügyeit. A föispán vele szemben - ahogy az egész vármegyei közigazgatással szemben is — csak ellenőrzési jogot gyakorolt.

A föszolgabíró a járás első tisztviselője volt, a vármegyei törvényhatósági bizottság a járás élére „élethosszig” választotta. A magyar közigazgatás egyetemes jellegű szervezete volt, eljárt köz- és állategészségügyi, anyakönyvi, erdészeti, gyám, gondnoksági, házassági, cseléd, ipari, népoktatási, vadászati, vásári, vízjogi stb. ügyekben és kihágási bíráskodást is gyakorolt. A főszolgabíró a községi közigazgatás közvetlen felügyelöjeként elnökölt egyes községi képviselötestületi közgyüléseken is. A községi közegekhez rendeleteket intézhetett és a nem engedelmeskedő vagy hanyag községi tisztviselőkkel szemben rendbírságolási és fegyelmi joga volt. Az alispán közvetlen felügyelete alatt müködött, tőle kapta utasításait. Bírói hatóságot is gyakorolt a kisebb polgári peres ügyekben való eljárásról szóló törvény szerint ${ }^{19}$ az egyszerübb peres ügyekben, valamint büntetőbíróként a közigazgatási hatóságok hatásköréhez utalt kihágások eseteiben.

E közigazgatási struktúra nagyban meghatározta a csendőrség rendes szolgálati teendőin kívül eső, karhatalmi, rendőri segély jellegü és egyéb felhívásra teljesített közbiztonsági szolgálatainak tartalmát és jogalapját.

\section{Karhatalom és „rendőri segély" a csendőrségi szolgálatban}

A csendőrség tevékenységi körében az arra feljogosított hatóság vagy tisztviselő felhívására illetve kirendelésére teljesített szolgálatok között el kell különíteni a karhatalmat, a rendóri segélyt és az ezekkel rokon tartalmú, de más jogalapon nyugvó felszólítás vagy rendelkezés folytán teljesitett közbiztonsági szolgálatot. E három fogalom, valamint a kusza jogszabályi szövegekben elrejtett fogalmi ismérveik hosszú időn át fejtörést okoztak a közigazgatási szervezeteknek.

A karhatalom fogalomkörének rendezetlensége gyakran zavart keltett a közigazgatásban, ami föként a nem megfelelő helyről kirendelt, nem helyesen igényelt vagy nem megnevezett fegyveres erő alkalmazásában nyilvánult meg. Ezt kísérelte meg feloldani az igazságügy miniszternek 1874. IV. 18án kelt a királyi törvényszékek elnökeihez és a királyi járásbírákhoz intézett körrendelete, ${ }^{20}$ amely a bírósági végrehajtások alkalmával igénybe vett „karhatalom” és „rendőri segély” fogalmát tisztázta. Az elhatárolás alapjának ekkor egyrészt a kirendelés jogcímét, másrészt a kirendelt erő nagyságát tekintették. Rendőri segély alatt elsősorban a polgári perrendtartásról szóló törvény ${ }^{21}$ szerinti ellenszegüléssel akadályozott végrehajtás foganatosítása érdekében igénybe vett erőt értették (bár a jogszabály szövege karhatalmat említ, ami végső soron a nem megfelelő értelmezés alapja is volt). Ilyen esetekben általában 1-2 közbiztonsági közeg elegendő a feladathoz, akiket az illetékes járási tisztviselő rendel ki.

Ha azonban az ellenállás olyan mértékü volt, hogy több járás pandúrjait, vagy súlyosabb esetben haderő csapatait kellett kirendelni, erre már csak az alispán volt jogosult. Mivel az összpontosított erő karhatalomnak minősült, annak kirendelésére a köztörvényhatóságok rendezéséről szóló 1870. évi törvényben foglaltak voltak érvényesek. ${ }^{22}$ Ezen törvényt hatályon kívül helyező - a törvényhatóságokról szóló 1886. évi - törvény értelmében az alispán a vármegye első tisztviselöjeként intézkedhetett a karhatalom kirendelése iránt. ${ }^{23}$ A végrehajtási eljárásról szóló 1868 . évi törvény ${ }^{24}$ helyébe lépő 1881. évi törvény még élesebben elkülönítette a karhatalom és a rendőri segély közti különbséget, miszerint az ellenszegülés leküzdése közbiztonsági közegek ,segélyével” eszközlendő, ${ }^{25}$ melyhez a megkeresést a hatóság képviselője közvetlenül intézi. A szükséges katonai karhatalom kirendelése érdekében a kiküldő a bírósághoz volt köteles fordulni. A fentiekböl látszik a közigazgatás folyamatos törekvése a két fogalom szétválasztására és eltérő tartalmuk érzékeltetésére.

A hatóságok folyamatos fogalmi zavarát jelzi azonban a közadók szedéséről szóló 1883. évi törvény, mely szerint az eljárás során a közbiztonságot szükség esetén karhatalom kirendelésével is fenn kell tartani. ${ }^{26}$ A rendelkezés azonban tartalmában rendőri segélyt takart és nem szükebb értelemben vett karhatalmi fellépést.

A fogalmak fordított felcserélésére is van példa a korabeli joggyakorlatban. A Magyar Királyi Csendőrség városi szolgálatellátásának lehetöségét szabályozó 1882 . évi törvény szerint ${ }^{27}$ olyan esetekben, mikor a városi rendőrség nem tudja fenntartani a közrendet, a városi hatóság vezetöje a „csendőrség segédkezését” igénybe venni jogosult. Ez azonban nem esik a rendőri segély fogalomkörébe, mivel a csendőrség nem saját szolgálati feladatai teljesítésére volt kirendelve, hanem hogy megjelenésével tekintélyt szerezzen a rendőrség intézkedéseinek. 
A büntető perrendtartásról szóló 1896. évi törvény szerint a terheltek elő́llításánál karhatalom vehető igénybe, ami azonban fogalmilag és tartalmát tekintve is helyes. ${ }^{28}$ Ennek oka, hogy a csendőr egyszerüen szolgálatot teljesített akkor, ha a terheltet bekísérte a hatósághoz és karhatalomként járt el, ha az elővezető parancs közönséges kényszereszközökkel nem volt foganatosítható, vagyis a terhelt ellenállt. Ekkor a karhatalom általános céljának tartalmi elemei teljesültek, a helyzet azonban a csekély bevetett létszám miatt sajátos volt.

A Magyar Királyi Csendőrség 1900. évi szolgálati utasítása szerint a csendőrjárőrt az erre feljogosított hatóság közvetlenül is igénybe veheti. A csendőrség felhívása itt szintén karhatalomként értelmezhető, mivel a polgári tisztviselő rendelkezéseinek érvényre jutását támogatja. Ha az erre feljogosított tisztviselö sürgős esetben a csendőrjárőrt közvetlenül keresi meg tágabb értelemben vett karhatalom kirendeléséröl beszélhetünk. ${ }^{29}$

A csendőrség tehát ha nem a rendes szolgálati teendőt végezte, hanem megjelenésével tartotta vissza az erőszakoskodást vagy polgári tisztviselök felhívására biztosította a törvényes rendelkezések akadálytalan végrehajtását, karhatalmi szolgálatot teljesített. A foglyok kísérése, őrzése, tárgyalások biztosítása éppen ezért nem karhatalmi, hanem a csendőri szolgálat „segélyének” igénybe vételét jelentette. $^{30}$

A fogalmak teljes körü tisztázását még inkább nehezíti a sem karhatalom, sem rendőri segély fogalomkörébe nem vonható intézkedések témája. Ilyenek voltak a több törvényben is megjelenő visszakísérés és kivezetés, melyek nem álltak másból, mint a munkavégzés helyéről távol maradt személy felhívása és kísérése rendszerint ellenállás nélkül. Itt a csendőr nem segélyt nyújtott egy hatóságnak, hanem közbiztonsági szolgálatot teljesített annak a szolgabírónak a rendelkezése folytán, akinek más közegek nem álltak rendelkezésére. ${ }^{31}$ A testület „szolgálati szabályzata” szerint az ilyen megkereséseket az illetékes közigazgatási hatóságok útján kellett megtenni. ${ }^{32}$

A cseléd és gazda közötti viszony szabályozásáról, a gazdasági munkásokról és a napszámosokról szóló 1876. évi törvénycikk szerint az a cseléd, aki szolgálatát a szerződési idő eltelte előtt elhagyja, a gazda kívánatára szolgálatába való visszatérésre hatóságilag volt kényszeríthető. ${ }^{33}$

A munkaadók és a mezőgazdasági munkások közötti jogviszony szabályozásáról szóló 1898. évi törvénycikk szerint, ha az elvállalt munka az időjárás miatt meg nem kezdhető vagy megakad, a munkások a munkaadó beleegyezése nélkül el nem távozhatnak. Ha a napszámos a meghatározott időben igazolatlanul meg nem jelen, vagy a megkezdett munkát abbahagyva jogtalanul eltávozik, az elsőfokú hatóság által - a munkaadó írásbeli, vagy jegyzőkönyvbe foglalt szóbeli kérelmére tárgyalás nélkül a munkahelyre kivezetése rendelendő el. ${ }^{34}$ A vízi munkálatoknál, az út- és vasútépítésnél alkalmazott napszámosokról és munkásokról szóló 1899 . évi törvénycikk, ${ }^{35}$ valamint az erdőmunkásokról szóló 1900. évi törvénycikk ${ }^{\mathbf{3 6}}$ szerint foglalkoztatottakra ugyanezek a rendelkezések voltak alkalmazhatók.

A vármegyei közigazgatás azonban nemcsak a fenti, felszólított közbiztonsági szolgálatokra alkalmazta a csendőrségi erőt, hanem sokszor mindenre alkalmasnak és kötelesnek tartotta. Ezért külön belügyminiszteri körrendeletben szabályozták, hogy a csendörséget nem lehet elvonni olyan feladatra, amely nem közvetlenül a szervezet rendeltetéséböl fakad (pl. betegek kórházba kísérésére). Ez is mutatja, hogy a csendőrség a közigazgatás felhívását köteles volt teljesíteni és ezek tartalmának országos szintű egységesítése hosszú időn keresztül fontos volt az állami vezetés számára. ${ }^{37}$

Amikor a karhatalom szabályozása mind tágabb, mind szükebb értelemben egyre részletesebbé vált azt a polgári közigazgatás kiemelt kérdésként kezelte. A szabályozás természetesen nemcsak közigazgatási, hanem a haderő oldalról is egyre részletesebbé vált.

A honvédelmi miniszter 1876. évi körrendeletével, valamint a mellékleteként kiadott utasítással első ízben teljes és pontos szabályozást biztosított mind a közhatóságok, mind a katonai parancsnokságai által követendő eljárás tekintetében. ${ }^{38}$ A rendelet leszögezi, hogy a haderő csapatait karhatalmi feladatok teljesítésére csakis abban az esetben lehet kirendelni, ha a „politikai hatóságok” rendelkezésére álló közbiztonsági erő nem elegendő. A legsürgősebb eseteket kivéve ezek a polgári hatóságok döntöttek saját erejük elégséges voltáról, illetve a haderő igényléséről. Ha a sürgős karhatalmi beavatkozás igénye miatt a kirendelő közvetlenül a haderő területileg illetékes állomás-parancsnokságához fordult, erről a belügyminiszternek táviratilag azonnal jelentést kellett tennie.

A rendelet mellékletét képezi az „,Utasitás a sorhadi vagy honvédségi karhatalomnak igénybevétele alkalmával a közhatóságok részéröl követendö eljárásról”, amely a karhatalom célját a következők szerint fogalmazza meg: „... a közhatóságok támogatása, hogy ez által azoknak törvényes rendelkezéseik és hivatalos müködéseik ellenében vetett eröszakos ellenállás ellen, a szükséges anyagi erö szolgáltassék." 39 
Az utasítás felsorolja azon hatóságokat és közegeket, akik közvetlenül fordulhattak a haderő parancsnokságaihoz karhatalmi igénnyel. A 2. pont k) alpontjában már itt megtalálható volt az erdélyi csendör-parancsnok és szárny-parancsnokok, amely a későbbi szabályozásban folyamatosan bővülő csendörségi személyi körrel is megtalálható volt. A felsorolt személyek a hadsereg legközelebbi helyőrséghez fordulhattak igényükkel a karhatalom céljának megjelölésével. A kiküldött erőt természetesen a karhatalmi feladatok teljesítésére felkészített alakulatok állományilletékes parancsnoka határozta meg. A Magyar Királyi Honvédség karhatalmat csak akkor szolgáltatott, ha az adott területen a közös hadsereg csapatai nem, vagy nem kellö létszámban álltak rendelkezésre.

Fontos korlátozó rendelkezés volt, hogy helyőrségen belül az állomás-parancsnok mindig kiállíthatott karhatalmi egységet, helyőrségen kívüli alkalmazásra azonban csak akkor, ha ezáltal a helyőrség katonai képességi jelentősen nem csökkentek. A halasztást nem türő esetekben a laktanya ügyeleti tisztjei és csapat-parancsnokai is küldhettek ki állományukból karhatalmi osztagot saját felelősségükre. Az elöre látható igények felterjesztése azonban mindig a Magyar Királyi Belügyminisztérium útján történt, amely a budapesti katonai hadfőparancsnokság útján intézkedett a teljesítésre.

A polgári hatóságok által kikért, a haderő karhatalmi feladatokat ellátó csapatainak tényleges fegyveres alkalmazásakor a közigazgatási tisztviselö háttérbe vonult és a további intézkedések tisztán katonai szempontok szerint történtek. ${ }^{40}$ Ez komoly garancia volt a katonai erő politikai vagy önös célokra történő felhasználása ellen, több részletszabály azonban nem volt teljesen kidolgozott.

A fenti rendelet és utasítás módosítására és átdolgozott újbóli kiadására a honvédelmi miniszter 1886. körrendeletével került sor 1887. I. 16-án. ${ }^{41}$ Az új rendelet mellékleteként kiadott „Utasitás a magyar korona országaiban a hadseregbeli vagy honvéd karhatalomnak igénybevétele alkalmával a közhatóságok részéröl követendö eljárásra nézve” jelentős módosításokat nem, inkább aktualizálást és a közigazgatási szervezet változásaihoz igazítást jelentett. Az utasítás 2. pont k) alpontja - a Magyar Királyi Csendőrség felállításából eredő megváltozott helyzet miatt — a haderö karhatalmának igénylésére közvetlenül feljogosított hatóságok és közegek között felsorolja a csendörség tiszti parancsnokságait, valamint szükség esetén minden szolgálatban levő csendőrt.

Az elöre látható karhatalmi igények kirendelési rendjében változást jelentett, hogy a Magyar Királyi Belügyminisztérium az illetékes hadtest-parancsnoksághoz továbbította a megkeresést. ${ }^{42}$

A szabályozás újabb módosítására és jelentős kiegészítésére a honvédelmi miniszter „Utasítás a magyar korona országaiban a hadseregbeli vagy honvéd karhatalomnak igénybevétele alkalmával a közhatóságok részéről követendő eljárásra nézve" címü 1896. évi rendeletének a kiadásával került sor. $^{43}$

Az utasítás a korábbiaktól eltérően jelentős részletszabályokat tartalmaz a karhatalmi fellépésre és az erők alkalmazására nézve. A 2. pont kiemeli, hogy a haderő karhatalmának kirendelését alaposan meg kell fontolni, mert a csendőri erő idejében történő alkalmazása és a rendbontókkal szembeni törvényes eljárás célravezetőbb, mint a katonai erődemonstráció. Ha a rendelkezésre álló csendőrségi erő nem elégséges a feladatok végrehajtásához, úgy a belügyminisztertől nagyobb csendőri összpontosítást kell kérni. A haderő a továbbiakban csak akkor vehető igénybe, ha az összpontosított csendőri erő sem elégséges. Megállapítható tehát, hogy az 1886-os utasítás óta a csendőri karhatalmi erő olyan mértékben felértékelődött, hogy azt már a csapaterös feladatok elsődleges végrehajtójának tekintették. Szükséges volt azonban szem előtt tartani azt is, hogy nagyobb területet érintő vagy súlyos, fegyveres harcot igénylő esetekben továbbra is a haderő karhatalma volt a közrend helyreállításának elsődleges eszköze. ${ }^{44}$

A korabeli jogértelmezés szerint tehát a konkrét harcfeladatra kirendelt karhatalmat továbbra is elsősorban a haderő szolgáltatta, és a csendőrség, valamint a rendőrségek fordulhattak a haderő karhatalmi segítségéért, emellett pedig saját szervezetükben is létrehozhatók voltak összpontosítások. ${ }^{45} \mathrm{~A}$ fövárosi rendőrségről szóló 1881 . évi törvény részletes leírása szerint a rendet és a közbékét komolyan veszélyeztető, nagyobb mérvü népcsoportosulás vagy tényleges lázadás esetében a sorkatonaság vagy honvédség „,segélye” igénybe vehető. Ennek tényleges fellépése előtt a fővárosi rendőrség egyik megbízott és külső jel által felismerhető tisztje, a veszélyes csoportosulás vagy lázadás helyén a zavargókat dobszó vagy harsona általi figyelmeztetés után a „törvény nevében” szavakkal békés szétoszlásra hangosan háromszor felhívja. Ennek eredménytelensége esetén a további intézkedéseket a karhatalom parancsnoka teszi meg. ${ }^{46}$

A rendőrségek - bár később a fővárosi rendőrség saját szervezetében is létrehozott karhatalmi alakulatot - összességében nem voltak alkalmasak a tömegkezelési feladatok ellátására, így ennek teljesítése céljából megfelelőbb fegyveres erőhöz fordultak. A fővárosi rendőrségről szóló 1881. évi 
törvény ${ }^{47}$ hatályba lépését követően a haderő karhatalmának igénylése mindinkább háttérbe szorult, helyette pedig egyre nagyobb szerephez jutott a csendőrség karhatalmi igénybe vétele.

A jogszabályokban foglaltaknál sokkal érdekesebb volt azonban az a helyzet, amikor egy karhatalmi képességekkel rendelkező szervezet képviselője más szervezet erejének kirendelését kérhette a szükség okán. A karhatalom témájában kibocsátott 1896.évi honvédelmi miniszteri rendelet a haderő karhatalmának igénylésére közvetlenül feljogosított hatóságok és közegek között továbbra is felsorolta a szolgálatban levő csendőrt is, azonban az elöre látható karhatalmi igényekkel a belügyminiszterhez csak a csendör-parancsnokok fordulhattak. ${ }^{48} \mathrm{Ez}$ is megerösíti azt a nézetet, miszerint a karhatalom kirendelését elsősorban nem a szervezet, hanem az adott feladatra való alkalmasság és képesség határozta meg, ami nagyon rugalmas és gyorsan reagáló karhatalmi struktúrát eredményezett.

A karhatalom témájában az 1896-ban kiadott honvédelmi miniszter utasításban újdonságot jelentett, hogy az igénybevétel módja részletesen szabályozásra került. A haderő karhatalmának igénylése írásban történt az alkalmazás céljának, idejének megjelölésével, valamint a karhatalommal történő kapcsolattartásra kijelölt hivatalos közeg feltüntetésével. További fontos, garanciális szabályként - a csendőrségi szolgálati utasítás rendelkezéseihez hasonlóan - megjelent, hogy a karhatalom a hatósági tevékenységben nem vehet részt. Ez a korlátozás olyan komoly volt, hogy a rendöri közegek elégtelensége esetén más hatóságok feljogosított tisztviselői, sőt még a hatóságok által kirendelt „részrehajlatlan bizalmi férfiak”, vagyis polgári személyek is igénybe vehetők voltak, de a katonák nem. ${ }^{49}$

Ugyanez a garanciális szabály állt a csendőrség karhatalmi fellépései mögött is, ami mind a kirendelő közigazgatási hatóságot, mind az eljáró csendőröket világos, átlátható felelösségi viszonyok közé szorította. Mindkét fél a saját müködésén belül bekövetkezett eseményekre reagálva hozta meg kizárólagos döntéseit és viselte azok felelősségét. Már a Magyar Királyi Csendőrségnek az „,Utasitás a Magyar Királyi Csendörség számára” címmel 1881-ben megjelent első szolgálati szabályzata is tartalmazta, hogy a csendőrség a közigazgatási hatóságok rendelkezése alatt áll. Ezek hivatalos felszólításainak feltétlenül engedelmeskedni tartozik és a felhívás megbírálásába nem bocsátkozhat. A meghagyás vagy meghívás tartalmáért azonban mindenkor az azt kiadó hatóság vagy egyén volt a felelős, ezek foganatosításáért, valamint eközben a törvények pontos betartásáért az eljáró csendőr. ${ }^{\mathbf{5 0}}$

Rendelkezésre állt tehát a kellő döntési szabadság a karhatalom alkalmazása során is, amelynek az 1896. évi vonatkozó tartalmú honvédelmi miniszteri rendelet szövege szerint - polgári hatóságot képviselő hivatalos közeggel „lehetőleg egyetértőleg” kellett történnie. A katonai vagy csendőrségi kordonok mellé mindig megfelelő számú rendőri erő vezénylése volt szükséges, hogy a közlekedők ellenőrzése, igazoltatása, feltartóztatása biztosított legyen. ${ }^{51}$

Az igazságügy miniszternek a karhatalom igénybevétele tárgyában kibocsátott rendelete az igazságügyi hatóságok számára is egyértelművé tette az új szabályozás kizárólagosságát és mellékletében közölte a karhatalmi utasítást is. ${ }^{52}$

A részletes szabályozás mellett az is jelezte a karhatalom jogszerü és szakszerü kirendelésének biztosítására tett folyamatos állami törekvéseket, hogy a közigazgatás legvégső rendteremtő eszközét felelötlenül alkalmazó személyeket felelösségre vonta. Aki a karhatalmat jogtalanul vette igénybe vette legalább kihágást követett el. A kihágásról szóló 1879. évi büntető törvénykönyv szerint, aki a hatóságot bármi módon félrevezeti, nyolc napig terjedő elzárással büntetendő, azonban akinek ténykedése nyomán a rendőri vagy fegyveres erő ténylegesen karhatalmat állít ki, 15 napig terjedő elzárásra számíthat. Ha a karhatalmat közhivatalnok rendelte ki jogosulatlanul, akkor annak minden felelösségét az esetleges fegyverhasználattal együtt - ő viselte és a büntető törvénykönyv szerint hivatali visszaélés bűntettét követte el. ${ }^{53}$ Itt mindenképpen szükséges tehát megkülönböztetni a fegyveres erő alkalmazását, ami megelőző jellegü és sokszor a puszta megjelenéssel, felvonulással is célt érhet, valamint a fegyveres erő használatát, ami egyúttal a fegyverhasználatot is magában foglalja annak minden következményével együtt.

A karhatalom pártcéloknak vagy magánérdekeknek megfelelő alkalmazását tehát a lehető legtöbb jogszabályi garancia bevezetésével kívánták elkerülni. Az esetleges negatív tapasztalatoknak megfelelően módosították a kirendelésre jogosultak körét. A föispánokat például az 1905. évi honvédelmi miniszteri rendelet ${ }^{54}$ felvette a csendőrség és a haderő karhatalmát igénybe venni jogosultak körébe, azonban ezt az 1906. évi belügyminiszteri rendelettel ${ }^{55}$ törölték. Ezt leginkább a föispánok politikai természetü feladatköre indokolta valamint az, hogy a karhatalom kirendelését az állam a közigazgatási apparátus erre felkészített tisztviselőire kívánta bízni. 


\section{Népgyülések kezelése}

A csendőrség 1900. évi szolgálati utasítása szerint a csendőrnek mindig kiemelt figyelmet kellett fordítania a munkásmozgalmakra, sztrájkokra és más csoportosulásokra, melyekről azonnal jelentést kellett tennie a közigazgatási hatóságnak. A népgyüléseknél vagy „csődüléseknél” a csendőrségnek a közigazgatási hatóság utasításai szerint kellett eljárnia, a gyakorlati végrehajtásra nézve azonban az általános jellegü rendelkezéseken túl kevés instrukciót kapott a szolgálati utasítástól. Ha csendőr tömeggel szemben volt kénytelen fellépni mindenek elött a „törvény nevében” szavakkal felhívta a résztvevőket a szétoszlásra, melynek eredménytelensége esetén a „fötényezőket” eltávolította. ${ }^{56}$ A gyülekezési jog szabályozása hosszú időn keresztül nem volt teljes és a „,közigazgatási hatóság utasításai” kaptak hangsúlyt a jogszabályi hiányok kitöltésekor. A jogi szabályozás fejlődésével azonban egyre jobban körülhatárolhatóvá vált a csendőri fellépés müködési tere és mindinkább jogi alapokon, nem pedig eseti rendelkezéseken nyugodott.

A népgyülések tárgyában kiadott 1898. évi belügyminiszteri körrendelet ${ }^{57}$ kihágásnak minősítette a feloszlatott népgyülések folytatását, ezáltal egyértelmü jogalapot teremtett a csendőrségi fellépések számára. A kihágási büntető törvénykönyvről szóló miniszteri rendelet szerint csak valamely rendőri tilalom megszegése minősülhetett kihágásnak, ${ }^{58}$ így a tömegkezelési, tömegoszlatási feladatok a jogi gondolkodásban is egyre inkább a polgári hatóságok kompetenciájába kerültek és mind a katonai fellépés, mind a kialakult helyzet haderővel történő központi jellegü kezelése háttérbe szorult.

A tárgykör legteljesebb szabályozása első ízben a gyülekezési jog gyakorlásáról szóló 1913. évi belügyminiszteri körrendelettel ${ }^{59}$ született meg, amely a törvényi szabályozás megalkotásáig hatályos átmeneti rendelkezés volt. Kiadásának indokai a tömegrendezvényeken egyre szaporodó erőszakos cselekmények és a karhatalmi fellépést követő vitás kérdések rendezése voltak. Rendelkezései szerint a rendőrhatóság magát minden nyilvános gyülésen kiküldöttje által képviseltetheti. A kiküldött köteles figyelemmel kísérni a gyülést és törvénysértés esetén a szervezőket felhívni a rendezvény feloszlatására, ennek sikertelensége esetén a gyülést feloszlatottnak nyilvánítani, melyet végső soron karhatalom igénybevételével biztosíthat. A rendelet legjelentősebb része a büntető rendelkezéseket tartalmazó C) rész, amely kihágási elkövetési magatartásként nevesíti többek között a betiltott rendezvényen való részvételt, a hatóság feloszlató intézkedésének való ellenszegülést, valamint a népgyülésen elkövetett erőszakos cselekményeket, dobálást. ${ }^{60}$

Ebben a jogi helyzetben már egyértelmű volt a csendőri karhatalom elsőbbsége a haderő karhatalmával szemben, mivel csak a csendőri karhatalom volt képes a kihágások elkövetőivel szemben is intézkedéseket foganatosítani, míg a haderő karhatalmának kompetenciája csak a „harcfeladat” végrehajtásáig terjedt.

A törvényi szabályozás sem sokáig váratott magára. A választói jog büntetőjogi védelméről, valamint az országgyülési képviselők választásáról szóló 1913. évi törvények ${ }^{61}$ súlyos büntetéseket állapítottak meg azokkal szemben, akik a választójog szabad gyakorlását erőszakos, megfélemlítő vagy megszégyenítő cselekményekkel zavarták meg vagy meghiúsították. Ha a cselekményt csoport követte el, a felbujtók és a vezetők büntetése súlyosabb volt, ami elfogásuk kötelezettségét rótta a csendőrségre. A „föcinkosok” és „felbujtók” elfogása folyamatosan jelen volt a csendörségi feladatok homlokterében, és végső soron ennek eszközéül szolgáltak a tömeg szétoszlatására tett intézkedések (pl. a szuronytámadás), amelyek kimozdították a tömeget és lehetőséget adtak az elkövetők kiemelésére. ${ }^{62}$

Összességében megállapítható, hogy a korszak magyar rendvédelmi struktúrája nem volt karhatalmi tevékenységre koncentrált, különösen nem a csapaterős rendvédelmi teendők tekintetében. A vizsgált időszakban a magyar gyakorlat azt a történelmileg jól bevált és takarékos megoldást követte, hogy szükség esetén a véderő alakulatait alkalmazták nagyobb létszámú, vagy egyszerre több helyen megvalósításra kerülő csapaterős karhatalmi feladat teljesítésére, mivel ilyen helyzetek ritkán álltak elő. A jogi szabályozás és a polgári állam fejlődésével azonban mindinkább előtérbe került a rendvédelmi karhatalom alkalmazása, melynek az a tény kedvezett leginkább, hogy a Magyar Királyi Csendőrség jellegénél fogva alkalmas és képes volt e feladat végrehajtására. A közigazgatási struktúrából és a rendfenntartásra vonatkozó korabeli felfogásból adódóan a karhatalom és határterületei ezer szálon kötődtek a polgári hatóságokhoz, így fellépésük folyamatos kontroll alatt állt. A jól szabályozott és számos garanciát tartalmazó normarendszer folyamatosan alkalmazkodott a társadalmi viszonyok változásához és a csendőrségi szervezet - ezen belül is a karhatalmi kötelékek - rugalmasan alkalmazkodtak a megváltozott követelményekhez. A csapaterős karhatalmi feladatok gyakorlati végrehajtási technikáinak és taktikai eljárásainak részletes bemutatását egy újabb tanulmány keretében tervezem bemutatni. 
Jegyzetek:

${ }^{1}$ PARÁDI József: Rendvédelem-karhatalom 1867-1945. 112.p.

${ }^{2}$ RAVAsz: A Magyar Királyi Honvédség karhatalmi jogosultságai. ; Idem: A Magyar Királyi Honvédség karhatalmi alkalmazásának szabályozása a Horthy-korban.

${ }^{3}$ NÉMETHY 9.p.

${ }^{4} 132$ 505/907.BM.r.

${ }^{5}$ A Magyar Királyi Igazságügy Minisztérium 1867. június 22-én kelt rendelete.

${ }^{6} 10$ 186/1873.IM.kr.

${ }^{7}$ SZUT-1881.3. $\S$

${ }^{8}$ PARÁDi József: Rendvédelem-karhatalom 1867-1945. : op.cit. 116.p.

${ }^{9}$ PARÁDI József: A magyar rendvédelem fejlesztési reformjai a XIX. század második felétöl a XX. század közepéig.

${ }^{10}$ PARÁDI: A Magyar Királyi Csendőrség megalakulása és müködése 1881-1918 ; PARÁDI : A Magyar Királyi Csendörség. Az elsö magyar polgári, központositott, közbiztonsági örtestület 1881-1945. ; PARÁDI: A magyar rendvédelem története. ; PARÁDI: A Magyar Királyi Csendőrség szervezete.

${ }^{11}$ KILIÁN

${ }^{12}$ SZIKINGER

${ }^{13}$ EGYED

${ }^{14}$ PARÁDI József: Rendvédelem-karhatalom 1867-1945. op.cit.

15 1912/LIII.tc.

${ }^{16} 10$ 767/1905.HM.kr. ; BALLA

${ }^{17}$ PARÁDI József: A Magyar Királyság rendvédelme 1867-1919.

18 1886/XXI.tc. 19. §, 68. §, 73. §.

19 „2. § A szolgabiró az igazságszolgáltatás gyorsitása végett ezen biráskodással azon esetben ruházandó fel: ha az a közigazgatás hátráltatása nélkül lehetséges és ha az illetö jogot végzett vagy elméleti birói vagy jogtudományi államvizsgát tett, vagy már birói hivatalt viselt."

1877/XXII.tc.

${ }^{20} 8405 / 1874$.IM.kr.

${ }^{21} 1868$ /LIV.tc. $379 . \S$

22 1870/XLII.tc.

23 1886/XXI.tc. op.cit. : $68 . \S$ o) pont

${ }^{24} 1868$ /LIV.tc. op.cit.

25 „32. $\S$ A végrehajtás foganatositását ellenmondással, kifogással vagy ellenszegüléssel gátolni nem szabad. A kiküldött, a mennyiben a végrehajtási cselekmény foganatositása szükségessé teszi, a végrehajtást szenvedö lakását és tartályait felnyittathatja és kutatásokat eszközölhet. Ellenszegülés esetében a végrehajtás az illetö törvényhatóság vagy község legközelebbi közbiztonsági közegének segélyével foganatositandó, melyhez a megkeresést a kiküldött közvetlenül intézi. A netalán szükséges katonai karhatalom megszerzése végett a kiküldött a kiküldö biróság fönökéhez köteles fordulni. A végrehajtásnak ellenszegülés által való meggátlása esetében, a kiküldött a bünvádi eljárás meginditása végett, hivatalból külön jelentést tartozik tenni."

1881/LX.tc.

26 „,78. § A közigazgatási hatóságok (községi elöljáróságok, szolgabirák, polgármesterek, alispánok, és az utóbbiakkal egyenlö rangban álló tisztviselök) kötelesek arról gondoskodni, hogy az 56-74. §-ban körülirt végrehajtási eljárás foganatositása alkalmával a közrend szükség esetében karhatalom kirendelése által is fentartassék.)" 1883/XLIV.tc.

27 ,3. § Oly egyes esetekben, midőn a csend, rend és közbiztonság az illető városi rendörség által fenn nem tartható, a városi hatóság fönöke, vagy törvényes helyettese a csendörség segédkezését igénybe venni jogosult." 1882/X.tc.

${ }^{28} 1896 /$ XXXIII.tc. $131 . \S$

${ }^{29}$ SZUT-1900. 30.

${ }^{30}$ K. NAGY III.rész. 280.p.

31 2000/1898.FM.r. 159.§) ; 90 977/1907.BM.r.

${ }^{32}$ SZUT-1900. op.cit. $94 . \S$

33 „57. § Azon cseléd, ki szolgálatát a szerzödési idö eltelte elött az 51. és 52. §-okban kijelölt okok nélkül elhagyja, a gazda kivánatára szolgálatába való visszatérésre hatóságilag kényszeritendö; azonban a gazda nem kényszerithetö arra, hogy ily cselédet visszafogadjon, vagy hogy bér és élelem fejében többet adjon, mint a cselédnek tényleges szolgálatáig járt.

A jogtalanul távozó cseléd a gazdának okozott kár megtéritésére kötelezendö s ezen kivül 4-24 frtig terjedö birsággal vagy megfelelö elzárással fenyitendö."

1876/XIII.tc.

${ }^{34}$ „36. § Ha az elvállat munka az időjárás miatt meg nem kezdhetö vagy megakad, a munkások a munkaadó beleegyezése nélkül el nem távozhatnak, $s$ ha a szerzödésben magukat erre kötelezték, tartoznak a munkaadó által kijelölendö más gazdasági munkát teljesiteni; viszont pedig a munkaadó, ha a szerzödésben az élelmezés, vagy élelmezési járandóság kiköttetett, köteles a munkások élelmezési járandóságát vagy élelmezését a munka szünetelése esetére is kiszolgáltatni.

53. § Ha a napszámos a meghatározott idöben igazolatlanul meg nem jelen, vagy a megkezdett munkát abban hagyva jogtalanul eltávozik, az elsöfoku hatóság által - a munkaadó irásbeli, vagy jegyzökönyvbe vett szóbeli kérelmére, elöleges tárgyalás nélkül a munkahelyre, kényszereszközök alkalmazásával is, - kivezetésre határozatilag elrendelendö. Ha pedig a munkát a munkahelyen önként megjelenve vagy kivezetés után sem kezdi meg, illetve nem folytatja, a 38. § megfelelö alkalmazásával a 62. § szerint megbüntetendö.

58. § Kihágást követ el és 30 napig terjedhetö elzárással és 600 koronáig terjedhetö pénzbüntetéssel büntetendö az a munkaadó:

a) a ki a munkás vagy napszámos kivezetését törvényes alap nélkül eszközölteti (37., 53. §),

b) a ki ezen törvény 32., 56. \$-aiban foglalt tilalmakat megszegi. 
Ugyanezen büntetéssel büntetendö az a gazdasági alkalmazott, a ki a munkásoktól felfogadásukért magának anyagi elönyöket köt ki, vagy ily elönyöket elfogad."

1898/II.tc.

35 „2. $\S$ A jelen törvény 1. $\S$-ában emlitett munkálatoknál alkalmazott napszámosokra és munkaadóikra nézve megfelelöen az 1898:II. tc. 46-56. §-aiban foglalt rendelkezések alkalmazandók.”

1899/XLI.tc.

${ }^{36}$ „32. $\S$ Ha a napszámos a meghatározott idöben igazolatlanul meg nem jelen, vagy a megkezdett munkát abban hagyva jogtalanul eltávozik; az elsőfoku hatóság által, - a munkaadó irásbeli, vagy jegyzökönyvbe vett szóbeli kérelmére - elöleges tárgyalás nélkül a munkahelyre, kényszereszközök alkalmazásával is, kivezetése határozatilag elrendelendö. Ha pedig a munkát a munkahelyen önként megjelenve, vagy kivezetés után sem kezdi meg, illetve nem folytatja, a 43. $\S$ szerint megbüntetendö."

1900/XXVIII.tc.

${ }^{37} 104$ 681/1906.BM.kr.

${ }^{38}$ 1962/1876.HM.kr.

${ }^{39}$ Loc.cit.

${ }^{40}$ Loc.cit.

41 4539/1886.HM.kr.

${ }^{42}$ Loc.cit.

${ }^{43}$ 6707/1896.HM.r.

${ }^{44}$ Loc.cit.

${ }^{45}$ K. NAGY op.cit. II. rész 265.p. ; 1881/XXI.tc. op.cit.

46,„31. § A fökapitány vagy helyettese jogaihoz tartozik, szükség esetében a sorkatonaság vagy honvédség közremüködését igénybe venni. Ezek igénybevétele csak végsö esetben történhetik, midön a rendörség a rend és béke fentartására meröben elégtelen.

32. § Ha a rendet és közbékét komolyan veszélyeztetö nagyobb mérvü népcsoportosulás vagy tényleges lázadás esetében, a sorkatonaság vagy honvédség segélye igénybe vétetik, ennek tényleges fellépése elött a fövárosi rendörség egyik megbizott, s külsö jel - nemzeti szinü vállszalag - által felismerhetö tisztje, a veszélyes összecsoportosulás vagy lázadás helyén a zavargókat dobszó vagy harsona általi figyelmeztetés után a „törvény nevében” békés szétoszlásra hangosan és azon hozzáadással hivja fel, hogy engedetlenség esetében a fegyveres erönek rögtöni alkalmazása fog bekövetkezni. A felhivás, a mennyiben a körülmények engedik, még kétszer és utoljára ismételtetik.

33. § E figyelmeztetések siker nélkül maradván, a rendörtiszt a vezénylö katona- vagy honvédtisztet felhivja, hogy a törvénynek erövel szerezzen foganatot.

34. § A vezénylö tiszt e felhivásra a katonai szabályzatok szerint saját felelösségére intézkedik, sérvényt szerezvén a törvénynek, s helyreállitván a rendet, a további teendők iránti intézkedést ismét a polgári hatóságnak adja át."

1881/XXI.tc. :op.cit.

${ }^{47}$ Loc.cit.

${ }^{48}$ 6707/1896.HM.r. op.cit. 3.pont h) alpont

${ }^{49}$ Loc.cit. 6. pont

${ }^{50}$ SZUT-1881. : op.cit. 7. §

${ }^{51} 6707 / 1896 . H M . r$. op.cit. 9.pont d) alpont

5258 440/1896.IM.r.

${ }^{53}$ K. NAGY : op.cit. III. rész. 277.p. ；1879/XL.tc. 40.§

${ }^{54}$ 9732/1905.HM.r.

55 7237/1906.BM.r. ; 40 192/1906.BM.kr.

${ }^{56}$ SZUT-1900. : op.cit.

${ }^{57}$ 766/1898.BM.kr.

${ }^{58} 1879 /$ XL.tc. : op.cit.

59 7430/1913.BM.kr.

${ }^{60}$ Loc.cit.

61 _ „19. § Aki az országgyülési képviselö választásokra választási határidöt megállapitó belügyminiszteri rendeletnek a hivatalos lapban való közzétételétöl, idöközi választásoknál pedig attól a naptól kezdve, amelyen a képviselöház vagy annak elnöke az uj választást elrendelte, a választási eljárás befejeztéig a választás elökészitésében eljáró jelöltet vagy kiséretének tagját vagy a választás elökészitése vagy megtartása érdekében eljáró személyt vagy a választási elökészületekben vagy a választásban résztvevö választót megdobálja vagy ellenük más eröszakos, megfélemlitö vagy megszégyenitö cselekményt követ el, kihágás miatt egy hónapig terjedhetö elzárással és hatszáz koronáig terjedhetö pénzbüntetéssel büntetendö.

Ha e cselekményt csoport követi el, a felbujtók és a vezetök büntetése két hónapig terjedhetö elzárás és száz koronától hatszáz koronáig terjedhetö pénzbüntetés."

1913/XXIII.tc.

- „,148. § Aki a 84. § értelmében be nem jelentett vagy meg nem engedett idöpontban és helyen pártgyülést, illetőleg be nem jelentett vagy eltiltott pártünnepélyt, körmenetet rendez, ugyszintén az, aki pártgyülésen, pártünnepélyen vagy körmeneten, a rendet zavarja, vagy a közrend fenntartása végett kiadott hatósági intézkedésnek, vagy a feloszlató hatósági intézkedésnek nem engedelmeskedik, amennyiben cselekménye sulyosabb beszámitás alá nem esik, kihágást követ el és egy hónapig terjedhetö elzárással és háromszáz koronáig terjedhetö pénzbüntetéssel büntetendö."

1913/XIV.tc.

${ }_{62}$ A csendörségi SZUT magyarázata. 27.p. 


\section{A jegyzetekben alkalmazott röviditések:}

\section{MONOGRÁFIÁK ÉS KISMONOGRÁFIÁK}

NÉMETHY

PARÁDI : A Magyar Királyi Csendörség. Az elsö magyar polgári, központosított, közbiztonsági örtestület 1881-1945.

PARÁDI: A magyar rendvédelem története.

\section{TANULMÁNYOK}

BALLA

EGYED

PARÁDI Rendvédelem-karhatalom 1867-1945.

PARÁDI: A magyar rendvédelem fejlesztési reformjai a XIX. század második felétől a XX. század közepéig

PARÁDI: A Magyar Királyság rendvédelme. 1867-1919.

PARÁDI: A Magyar Királyi Csendőrség megalakulása és müködése 1881-1918.

PARÁDI: A Magyar Királyi Csendőrség szervezete.
- NÉmethy Ferenc: A m. kir. csendörség szervezete, szolgálata és viszonya a közigazgatási hatóságokhoz. Budapest, 1900, Országos Központi Községi Nyomda. /Közigazgatási Könyvtár./

- PARÁDI József: A Magyar Királyi Csendörség. Az elsö magyar polgári, központositott, közbiztonsági örtestület 1881-1945. Budapest, 2012, Szemere Bertalan Magyar Rendvédelem-történeti Tudományos Társaság. 281 p. HU-ISBN 97896308 4794 0. /A magyar rendvédelem-történet öröksége, 2./ HU-ISSN 2062-8447.

PARÁDI József et. Al. (szerk.): A magyar rendvédelem története. Budapest, $1996^{2}$, Tipico Design Kft. 317 p. HU-ISBN 963046215 X.

- Balla Tibor: A Magyar Királyi Honvéd Lovasság karhatalmi célú alkalmazása a dualizmusban. Rendvédelem-történeti Füzetek (Acta Historiae Preasidii Ordinis), XV.évf. (2008) 18.sz. 13-15.p. HU-ISSN 1216-6774. A tanulmány korábbi változata 2004. október 13-án, Budapesten hangzott el a Szemere Bertalan Magyar Rendvédelem-történeti Tudományos Társaság által szervezett rendvédelem-történeti tudományos konferenciasorozatnak a „Karhatalmi feladatok a bünmegelözés és a békefenntartás szolgálatában Európában a XIX-XX. században." címü XVIII. konferenciáján. A publikált tanulmány az előadás javított, bővített és átdolgozott változata.

- EgYed István: Karhatalom az önkormányzatban. Városi Szemle, Különlenyomat a 9. számból (1912. szeptember) Budapest, 1912, Székesfóvárosi házinyomda. 529-534.p.

- PARÁdi József: Rendvédelem-karhatalom 1867-1945. Rendvédelemtörténeti Füzetek (Acta Historiae Preasidii Ordinis), XX.évf. (2011) 23.sz. 111-123.p. A tanulmány korábbi változata 2009. október 9-én, Budapesten hangzott el a Szemere Bertalan Magyar Rendvédelem-történeti Tudományos Társaság által szervezett rendvédelem-történeti tudományos konferenciasorozatnak a „A kiegyezéstől az ezredfordulóig felszámolt országos hatáskörü magyar rendvédelmi testületek" címü XXIII. konferenciáján. A publikált tanulmány az előadás javított, bővített és átdolgozott változata.

- PARÁDI József: A magyar rendvédelem fejlesztési reformjai a XIX. század második felétől a XX. század közepéig. Rendvédelem-történeti Füzetek (Acta Historiae Preasidii Ordinis), XV.évf. (2008) 18.sz. 98-112.p. HU-ISSN 1216-6774. A tanulmány korábbi változata 2004. október 13-án, Budapesten hangzott el a Szemere Bertalan Magyar Rendvédelem-történeti Tudományos Társaság által szervezett rendvédelem-történeti tudományos konferenciasorozatnak a „,Karhatalmi feladatok a bünmegelözés és a békefenntartás szolgálatában Európában a XIX-XX. században." címü XVIII. konferenciáján. A publikált tanulmány az előadás javított, bővített és átdolgozott változata.

PARÁDI József: A Magyar Királyság rendvédelme 1867-1919. Rendvédelem-történeti Füzetek (Acta Historiae Preasidii Ordinis), IX.évf. (1999) 10.sz. 98-147.p. HU-ISSN 1216-6774. A tanulmány korábbi változata 1998. szeptember 22-én, Budapesten hangzott el a Szemere Bertalan Magyar Rendvédelem-történeti Tudományos Társaság által szervezett rendvédelem-történeti tudományos konferenciasorozatnak „, A nyugati rendvédelem hatása a XIX-XX. századi magyar rendvédelemre” címü X. konferenciáján. A publikált tanulmány az előadás javított, bővített és átdolgozott változata.

PARÁDI József: A Magyar Királyi Csendőrség megalakulása és müködése 1881-1918. Rendvédelem-történeti Füzetek (Acta Historiae Preasidii Ordinis), VII.évf. (1997) 8.sz. 78-83.p. HU-ISSN 1216-6774. A tanulmány korábbi változata 1996. október 29-én Budapesten hangzott el a Szemere Bertalan Magyar Rendvédelem-történeti Tudományos Társaság által szervezett magyar rendvédelem-történeti tudományos konferenciasorozatnak ,A napóleoni közbiztonsági örtestület útja Párizstól — Itálián és Ausztrián keresztül — Budapestig.” címü VIII. konferenciáján. A tanulmány az előadás javított, bővített és átdolgozott változata.

PARÁDI József: A Magyar Királyi Csendőrség szervezete. Rendvédelemtörténeti Füzetek (Acta Historiae Preasidii Ordinis), XXI.évf. (2011) 24.sz. 80-90.p. HU-ISSN 1216-6774. A tanulmány korábbi változata 2009. december 3-án Budapesten hangzott el a Szemere Bertalan Magyar Rendvédelemtörténeti Tudományos Társaság által szervezett magyar rendvédelem-történeti tudományos konferenciasorozatnak „Csendörség Ausztria-Magyarországon, illetve Ausztriában és Magyarországon 1849-2005. " Címü XXIV. konferenciáján. A tanulmány az előadás javított, bővített és átdolgozott változata. 
RAVASZ: A Magyar Királyi Honvédség karhatalmi jogosultságai.

RAVASz: A Magyar Királyi Honvédség karhatalmi alkalmazásának szabályozása a Horthy-korban.

SZIKINGER

\section{CIKKEK}

K. NAGY

KILIÁN

SZABÁLYZATOK

SZUT-1881.

SZUT-1900

A csendörségi SZUT magyarázata.

\section{TÖRVÉNYEK}

1868/LIV.tc.

1870/XLII.tc.

1876/XIII.tc.

1877/XXII.tc.

1879/XL.tc.

1881/XXI.tc.

1881/LX.tc.

1882/X.tc.

1883/XLIV.tc.

1886/XXI.tc.

1896/XXXIII.tc.

1898/II.tc.

1899/XLI.tc.

1900/XXVIII.tc.

1912/LXIII.tc.

1913/XIV.tc.

1913/XXIII.tc.
RAVASZ István: A Magyar Királyi Honvédség karhatalmi jogosultságai. Rendvédelem-történeti Füzetek (Acta Historiae Preasidii Ordinis), V. évf. (1995) 6.sz. 81-88.p. HU-ISSN 1216-6774. A tanulmány korábbi változata 1994. októberében, Budapesten hangzott el a Szemere Bertalan Magyar Rendvédelem-történeti Tudományos Társaság által szervezett magyar rendvédelem-történeti tudományos konferenciasorozatnak ,A két világháború közötti Magyar Királyság rendvédelme." címü VI. konferenciáján. A tanulmány az előadás javított, bővített és átdolgozott változata.

- RAvasz István: A Magyar Királyi Honvédség karhatalmi alkalmazásának szabályozása a Horthy-korban. Hadtörténelmi Közlemények, CXIX. Évf. (2004) 1. sz. 269-284. p. HU-ISSN

- SzIKINGer István: A rendvédelmi jog szabályozása a dualizmus korában. Rendvédelem-történeti Füzetek (Acta Historiae Preasidii Ordinis), III.évf. (1993) 4.sz. 187-198. p. HU-ISSN 1216-6774. A tanulmány korábbi változata 1992. szeptember 29-én, Budapesten hangzott el a Szemere Bertalan Magyar Rendvédelem-történeti Tudományos Társaság által szervezett rendvédelemtörténeti tudományos konferenciasorozatnak a „A dualista Magyarország rendvédelme." Címü IV. konferenciáján. A publikált tanulmány az előadás javított, bővített és átdolgozott változata.

- K. NAGY Sándor: Karhatalom.

Csendörségi Lapok, III.évf. (1909) 22.sz. 253-255.p. I. rész. Csendörségi Lapok, III.évf. (1909) 23.sz. 265-267.p. II. rész Csendörségi Lapok, III.évf. (1909) 24.sz. 277-281 .p. III. rész.

- Kilián Zoltán: Francia csendőrélet. Csendőrségi Lapok, XIX.évf. (1929) 19.sz. 571-573.p.

- Utasitás a Magyar Királyi Csendőrség számára. Budapest, 1881, Pesti Könyvnyomda Rt. 191 p.

- Szervezeti és szolgálati utasitás a Magyar Királyi Csendőrség számára. Budapest, 1900, Pesti Könyomda. 361 p.

- A csendőrségi SZUT magyarázata. Budapest, 1909, Kaufman Á. És Fiai.

- 1868/LIV.tc. a polgári törvénykezési rendtartás tárgyában.

- 1870/XLII.tc. a köztörvényhatóságok rendezéséröl.

- 1876/XIII.tc. a cseléd és gazda közötti viszony szabályozásáról, a gazdasági munkásokról és a napszámosokról.

- $\quad$ 1877/XXII.tc. a kisebb polgári peres ügyekben való eljárásról.

- 1879/XL.tc. a magyar büntetőtörvénykönyv a kihágásokról.

- 1881/XXI.tc. a Budapest-fővárosi rendőrségről.

- 1881/LX.tc. a végrehajtási eljárásról.

- 1882/X.tc. a magyar királyi csendőrség által, a törvényhatósági joggal felruházott városok kül- és belterületein való teljesítendőkről.

- 1883/XLIV.tc. a közadók kezeléséröl.

- 1886/XXI.tc. a köztörvényhatóságokról.

- 1896/XXXIII.tc. a bűnvádi perrendtartásról.

- 1898/II.tc. a munkaadók és mezőgazdasági munkások közötti jogviszony szabályozásáról.

- 1899/XLI.tc. a vízmunkálatoknál, az út- és vasútépítésnél alkalmazott napszámosokról és munkásokról.

- 1900/XXVIII.tc. az erdő-munkásokról.

- 1912/LXIII.tc. a háború esetére szóló kivételes intézkedésekről.

- 1913/XIV.tc. az országgyülési képviselők választásáról.

— 1913/XXIII.tc. a választói jog büntetőjogi védelméről. 


\section{RENDELETEK}

A Magyar Királyi Igazságügy Minisztérium 1867. június 22-én kelt rendelete.

10 186/1873.IM.kr.

8405/1874.IM.kr.

1962/1876.HM.kr.

4539/1886.HM.kr.

6707/1896.HM.r.

58 440/1896.IM.r.

766/1898.BM.kr.

2000/1898.FM.r.

9732/1905.HM.r.

10 767/1905.HM.kr.

40 192/1906.BM.kr.

104 681/1906.BM.kr.

90 977/1907.BM.r.

132 505/1907.BM.r.

7430/1913.BM.kr.
- A Magyar Királyi Igazságügy Minisztérium 1867. június 22-én kelt rendelete. A katonai karhatalomnak végrehajtásoknáli igénybe vétele tárgyában. Magyarországi törvények és rendeletek tára, I.évf. (1867) 1.füzet. 174.p.

- 10 186/1873.IM.kr. a karhatalom költségeinek elszámolása tárgyában. Magyarországi Rendeletek Tára VII.évf. (1873) 1.füzet. 182-183. p.

- 8405/1874.IM.kr. a bírósági végrehajtások alkalmával a karhatalomnak s illetőleg a rendőri segélynek miképpen leendő igénybe vétele tárgyában. Magyarországi Rendeletek Tára, VIII. (1874) 1. füzet. 341-342.p.

- 1962/1876.HM.kr. utasítás a sorhadi vagy honvédségi karhatalomnak igénybevétele alkalmával a közhatóságok részéről követendő eljárásról. Magyarországi Rendeletek Tára, X.évf. (1876) 1. füzet. 285-289.p.

- 4539/1886.HM.kr. Utasítás a sorhadi vagy honvédségi karhatalomnak igénybevétele alkalmával a közhatóságok részéről követendő eljárásról. Magyarországi Rendeletek Tára, XII.évf. (1887) 1.füzet. 22-29.p.

- 6707/1896.HM.r. Utasítás a magyar korona országaiban a hadseregbeli vagy honvéd karhatalomnak igénybevétele alkalmával a közhatóságok részéről követendő eljárásra nézve.

Magyarországi Rendeletek Tára, XX.évf. (1896) 1.füzet. 385-395.p.

- 58 440/1896.IM.r. a karhatalom igénybe vételéről szóló 8405/1874. IM. utasítás módosításáról.

Igazságügyi Közlöny, V.évf. (1896) 11.sz. 357.p.

- 766/1898.BM.kr. a népgyülések tárgyában. Belügyi Közlöny, III.évf. (1989) 5.sz. 90.p.

- 2000/1898.FM.r. a munkaadók és a mezőgazdasági munkások közötti jogviszonyoik szabályozásáról szóló 1898/II.tc. végrehajtása, továbbá az igazolványok kiállítása, az elveszett, megtelt vagy megsemmisült igazolványok megújítása körüli eljárás, valamint az eljárási szabályok tárgyában. Magyarországi Rendeletek Tára, XXXII.évf. (1898) 299-363.p.

- 9732/1905.HM.r. a csendőrségi utasítás módosításáról. Magyarországi Rendeletek Tára, XXXIX.évf. (1905) II.köt. 1269.p.

- 10 767/1905.HM.kr. a közös hadseregbeli és a honvédségi karhatalom igénybevétele tárgyában.

Magyarországi Rendeletek Tára, XXXIX.évf. (1905) I.köt. 384.p.

- 40 192/1906.BM.kr. a főispánok karhatalom-igénybevételi jogának megszüntetéséről. Magyarországi Rendeletek Tára, XL.évf. (1906) 4.füzet. 1004.p.

- 104 681/1906.BM.kr. a csendőrség betegek kórházba kísérése miatt igénybevételéről. Belügyi Közlöny, XII.évf. (1907) 8.sz. 69.p.

- 90 977/1907. BM.r. a járási főszolgabíráknak a mezőgazdasági munkások elővezetésére vonatkozó és a nem a területükön fekvő csendőr őrsökhöz szóló megkereséseiket, ezen örsökhöz az illetékes közigazgatási hatóságok útján kell intézniük.

Belügyi Közlöny, XII.évf. (1907) 40.sz. 384.p.

- 132 505/1907.BM.r. a ácsendőr járőrök megerősítése tárgyában. Belügyi Közlöny, XIII. (1908) 8.sz. 71.p.

- 7430/1913.BM.kr. a gyülekezési jog gyakorlásáról. Magyarországi Rendeletek Tára, XLVII.évf. (1913) 4.füzet. 1298-1301.p. 


\section{A csendörök fegyverhasználatának szabályozása \\ a testület 1881. évi elsö „szolgálati szabályzat”-ában.}

„11. §.

A szolgálatot teljesítő csendőr fegyverének használatára mindenki ellen jogosítva van:

1. a ki a csendőrt erőszakosan megsérti vagy őt támadással veszélyesen fenyegeti;

2. ha a tetten ért gonosztevő vagy alapos gyanúval terhelt egyén felfegyverkezve lévén, az előzetes felszólítás daczára magát önként meg nem adja, vagy esetleg védett helyzetéböl elöjönni vonakodik;

3. a ki figyelmeztető utasításainak — őt szolgálata teljesítésében meggátalonadó — tettlegesen ellenszegül;

4. a ki mint veszélyes gonosztevő a csendőrség által elfogatik, vagy őrizete alá adatik és bár erőszakos ellenállás nélkül, de a megállításra czélzó fenyegető rákiáltás daczára elfut, ha visszatartóztatására más mód nem létezik;

5. a ki ellenséges viszonyok között magát gyanússág teszi és a felhívásra kielégítő válasz nélkül elszalad.

Ha a fegyvernek a fent elősorolt esetekben történt alkalmazása folytán, az ellenszegülőnek testileg súlyos megsértése vagy annak halála következett be, akkor a tényálladék minden mellékkörülményekkel együtt honvédbíróságilag kinyomozandó és az eredmény az érdekelt csendör vallomásaival összehasonlítandó.

Ha az e végre kiküldött bizottság határozatilag kimondja, hogy a csendör a szolgálati utasításokhoz képest kötelessége szerint járt el, ez a csendőr-parancsnokság által napiparancsilag közzéteendő; ha azonban oly jogos gyanúokok mutatkoznak, melyeknél fogva a csendőr fegyverhasználati jogával való visszaéléssel jogosan vádolható, ellene a bizottság ebbeli véleménye alapján a hadi törvényszéki vizsgálat rendelendő el.

Ily esetekben előforduló könnyü sértések folytán való eljárás az illető csendőr-parancsnok hatáskörébe tartozik.

\section{2. .}

A csendőr, szolgálatának teljesítésekor, jogosult mindennemü közszolgálatban álló közegnek, különösen a polgári és más őrtestek és ezek tagjainak, nemkülönben község-elöljáróknak és katonai- vagy honvéd-parancsnokságoknak támogatását igényben venni."

,50. §.

Azon esetek, melyekben a csendőrnek fegyverét szabad használni, a szervezeti utasítás 11. §-ában vannak meghatározva.

De a csendőr ezen esetekben is fegyverét csak azután használja, miután minden egyéb eszköz alkalmazása eredmény nélkül maradt, s ekkor is még a legnagyobb kímélettel járjon el.

Ennél fogva, és a mennyiben azt a viszonyok engedik, előbb a kevésbé veszélyes fegyverek (a kard vagy szurony) használandó; mire nézve határozó befolyással még az is bír, hogy vajon a törvénysértő szintén fegyverrel vagy milyen sértő eszközzel van ellátva.

Ellenszegülésnél vagy valamilyen csendőrre intézett támadásnál utóbbinak mindenek elött arra kell törekednie, hogy az illető személyt az ellenállásra, esetleg megszökésre képtelenné tegye.

Ehhez képest lehetőleg azt is számításba kell vennie, hogy mily nemü fegyver és mily irányban használandó, hogy az ember élete lehetőleg kíméltessék és más személyek se veszélyeztessenek.

Ha valamely ellenszegülő a fegyvernek vele szemben alkalmazott használata következtében megsebesíttetett, akkor a csendör azonnal az illető ápolásáról gondoskodni tartozik.”

Forrás ! Utasítás a Magyar Királyi Csendőrség számára. 7-8.p. + 107-108.p. Budapest, 1881, Pesti Könyvnyomda Rt. 191 p. 